\title{
Nutrient Deficiency Promotes the Entry of Helicobacter pylori Cells into Candida Yeast Cells
}

\author{
Kimberly Sánchez-Alonzo ${ }^{1}$, Fabiola Silva-Mieres ${ }^{1}$, Luciano Arellano-Arriagada ${ }^{1}$, Cristian Parra-Sepúlveda ${ }^{1}$, \\ Humberto Bernasconi ${ }^{2}$, Carlos T. Smith ${ }^{1}\left(\mathbb{D}\right.$, Víctor L. Campos ${ }^{3}\left[\right.$ and Apolinaria García-Cancino ${ }^{1, *(D)}$
}

1 Laboratory of Bacterial Pathogenicity, Department of Microbiology, Faculty of Biological Sciences, Universidad de Concepcion, Concepción 4070386, Chile; kimsanchez@udec.cl (K.S.-A.); fabiolalsilva@udec.cl (F.S.-M.); lucarellano@udec.cl (L.A.-A.); cparras@udec.cl (C.P.-S.); csmith@udec.cl (C.T.S.)

2 Laboratorio Pasteur, Concepción 4030000, Chile; hbernasconi@lpasteur.cl

3 Laboratory of Environmental Microbiology, Department of Microbiology, Faculty of Biological Sciences, Universidad de Concepción, Concepción 4070386, Chile; vcampos@udec.cl

* Correspondence: apgarcia@udec.cl; Tel.: +56-41-2204144; Fax: +56-41-2245975

Citation: Sánchez-Alonzo, K.; Silva-Mieres, F.; Arellano-Arriagada, L.; Parra-Sepúlveda, C.; Bernasconi,

H.; Smith, C.T.; Campos, V.L.; García-Cancino, A. Nutrient Deficiency Promotes the Entry of Helicobacter pylori Cells into Candida Yeast Cells. Biology 2021, 10, 426. https://doi.org/10.3390/ biology10050426

Academic Editor: Maikel

P. Peppelenbosch

Received: 30 March 2021

Accepted: 4 May 2021

Published: 12 May 2021

Publisher's Note: MDPI stays neutral with regard to jurisdictional claims in published maps and institutional affiliations.

Copyright: (c) 2021 by the authors. Licensee MDPI, Basel, Switzerland. This article is an open access article distributed under the terms and conditions of the Creative Commons Attribution (CC BY) license (https:// creativecommons.org/licenses/by/ $4.0 /)$.
Simple Summary: Helicobacter pylori is a pathogenic bacterium which causes several gastric and extra-gastric pathologies in humans. This pathogen is capable of entering eukaryotic cells of humans or of other species, including yeasts of the genus Candida. These yeasts are resistant to stressing environmental conditions (such as $\mathrm{pH}$ changes or scarce nutrients) which threaten the viability of H. pylori. Therefore, Candida yeasts may harbor this bacterium when subjected to stressing conditions or become transmission vehicles for it. Further research is required to establish the stressing environmental factors triggering the harboring of $H$. pylori within yeasts. The present work evaluated if deficiency or absence of the necessary nutrients favors the endosymbiotic relationship between these two microorganisms, facilitating the viability of the bacterium. In fact, a deficiency of nutrients increased the harboring of viable H. pylori cells within the yeast cells. On the contrary, in the complete absence of nutrients, the presence of intra-yeast bacteria was reduced. Therefore, yeast cells may contribute to the subsistence of this pathogenic bacterium when subjected to nutrient deficiency until it may infect an appropriate host, such as humans. The present work may also contribute, with further studies, to elucidate the transmission routes used by the pathogen $H$. pylori to infect its hosts.

Abstract: Helicobacter pylori, a Gram-negative bacterium, has as a natural niche the human gastric epithelium. This pathogen has been reported to enter into Candida yeast cells; however, factors triggering this endosymbiotic relationship remain unknown. The aim of this work was to evaluate in vitro if variations in nutrient concentration in the cultured medium trigger the internalization of H. pylori within Candida cells. We used H. pylori-Candida co-cultures in Brucella broth supplemented with $1 \%, 5 \%$ or $20 \%$ fetal bovine serum or in saline solution. Intra-yeast bacteria-like bodies (BLBs) were observed using optical microscopy, while intra-yeast BLBs were identified as $H$. pylori using FISH and PCR techniques. Intra-yeast H. pylori (BLBs) viability was confirmed using the LIVE/DEAD BacLight Bacterial Viability kit. Intra-yeast $H$. pylori was present in all combinations of bacteriayeast strains co-cultured. However, the percentages of yeast cells harboring bacteria (Y-BLBs) varied according to nutrient concentrations and also were strain-dependent. In conclusion, reduced nutrients stresses H. pylori, promoting its entry into Candida cells. The starvation of both H. pylori and Candida strains reduced the percentages of Y-BLBs, suggesting that starving yeast cells may be less capable of harboring stressed H. pylori cells. Moreover, the endosymbiotic relationship between $H$. pylori and Candida is dependent on the strains co-cultured.

Keywords: Helicobacter pylori; nutrient deficiency; starvation; intracellular H. pylori; Candida; endosymbiosis; fetal bovine serum 


\section{Introduction}

Helicobacter pylori is a bacterial pathogen which infects the gastric epithelium of more than $50 \%$ of the world population. The infection caused by this bacterium may produce gastric and extra-gastric pathologies [1,2]. Gastric pathologies include an acute/chronic gastritis present in $100 \%$ of the infected population which, when not treated, may progress to more severe conditions, including atrophic gastritis, intestinal metaplasia and, even more severe, gastric cancer [3-5]. Since 1994, H. pylori has been considered to be a type I carcinogen for humans by the Agency for Research on Cancer [6]. Gastric cancer is the fifth most common cancer in humans and third in cancer-caused deaths worldwide [4]. Although not all $H$. pylori infected persons will develop this type of cancer, the literature reports the close relationship between the infection with $H$. pylori and the progression to gastric cancer [4]. Therefore, the Maastricht V Consensus established that all persons positive for $H$. pylori require antibiotic treatment [7]. Among the extra-gastric pathologies caused by $H$. pylori, it is possible to mention, among others, idiopathic thrombocytopenic purpura and iron deficiency anemia $[8,9]$.

The conditions provided by the gastric environment where $H$. pylori survives are challenging to replicate in the laboratory, making this pathogen a fastidious microorganism to culture in vitro [10-12]. Enriched culture media, such as Brucella agar or broth, Columbia agar (CA), brain heart infusion agar, or trypticase soy agar, provide the nutritional requirements for bacterial isolation. Due to its role as an enzymatic cofactor and its role in electron transport, iron is an essential element for the metabolism of organisms [13,14]. Therefore, all culture media to culture $H$. pylori must be supplemented with an iron source such as $5 \%$ to $10 \%$ horse blood or serum. Fetal bovine serum (FBS) can be used as an alternative (at the same concentrations), and Brucella broth can be supplemented with either $5 \%$ to $10 \%$ FBS or equine serum [15]. In both cases, supplementation with blood or serum provides the same function, serving as an iron source for $H$. pylori $[12,15,16]$.

Despite the nutritional and environmental demands required by H. pylori, this bacterium can be detected using molecular techniques in the oral cavity, amplifying specific genes of this microorganism in dental plaque, saliva, dental pulp, and in $30 \%$ of cases of severe cavities in children between 4 and 7 years [17-19]. Furthermore, the genes of $H$. pylori have been amplified by PCR from environmental sources such as tap water, insects (e.g., flies and blowflies), raw sheep meat, feces and raw milk from cows, buffaloes and sheep [20-23]. The diversity of environmental sources from where H. pylori genes have been amplified and the difficulty of isolating this bacterium from those sources raise the following questions: how does $H$. pylori DNA reach extra gastric locations? Is the survival of this bacterium possible in extra-gastric niches?

It has been reported that $H$. pylori in extra-gastric environments is capable of varying its morphology from helical to coccoid (viable non-culturable stage) [24,25]. It has also been observed that under specific environmental stimuli such as cold stress, $\mathrm{pH}$, aerobiosis, and aging, its metabolism of ATP, polyphosphate and RNA can vary, and its urease activity decreases $[18,19]$. Under FBS starvation, the bacterium, in addition to decreasing its metabolism, is capable of forming biofilms to ensure its survival $[25,26]$. However, if the stress conditions are not reversed in time, bacterial death will occur, and therefore, the question of how H. pylori survives in extra-gastric niches remains unanswered. In this sense, further investigation could unravel the intracellular association between $H$. pylori and yeast cells.

Most of the Candida species hosted by humans colonize the oral cavity, lungs, skin, stomach, intestine, vagina and urinary tract [27], and they can be vertically transmitted from the mother to the child during birth $[28,29]$. Yeast cells present in those niches may interact with different bacterial species, including the harboring of bacteria within yeast cells [27], and facilitate the bacterial dissemination throughout the host.

Yeast cells harboring bacteria-like bodies (Y-BLBs) have been isolated from different niches, such as the oral cavity of adults and newborns, gastric biopsies, vaginal discharge from pregnant women, fruits, flowers, different foods, and insects [30-36]. These observa- 
tions led to the suggestion that the vacuoles of fungal cells constitute a specialized survival niche for H. pylori, providing protection to this pathogen when it is subjected to environmental stressing conditions [37]. This proposal is further supported by assays co-culturing H. pylori and Candida albicans under low $\mathrm{pH}$ conditions ( $\mathrm{pH} 3-4)$, which demonstrated a higher percentage of yeast cells harboring this bacterium in co-cultures at acidic $\mathrm{pH}$ when compared to controls at neutral $\mathrm{pH}$ [38]. This result is indicative of a higher entry of $H$. pylori into C. albicans under $\mathrm{pH}$ conditions unfavorable for the bacteria [38]. Based on these findings, it is necessary to evaluate other environmental factors, such as nutrition conditions, that may promote the internalization of $H$. pylori into yeast cells and influence bacterial transmission and protection. Therefore, the aim of the present work was to evaluate in vitro if variations in FBS concentration in the culture medium can trigger the internalization of $H$. pylori into Candida cells.

\section{Materials and Methods}

\subsection{Bacterial Strains and Growth Conditions}

Four Candida strains were used in this study. These strains were the reference strains C. albicans ATCC 90028 and Candida glabrata ATCC 90030 and the clinical strains C. glabrata LEO-37 (obtained from the oral cavity) and C. albicans VT-3 (obtained from vaginal discharge). Four H. pylori strains were used: three of them were reference strains SS1, G-27 and J99 (also known as ATCC 700824), and the fourth one was the clinical strain H707 (obtained from a gastric biopsy). Yeast cells were cultured in Sabouraud agar (SA) (Merck, Darmstadt, Germany) plus chloramphenicol (CHL) (OXOID, Basingstoke, UK) following the manufacturer's instructions. Yeast cultures were incubated at $37^{\circ} \mathrm{C}$ for $24 \mathrm{~h}$ in an incubator under aerobiosis (ZHICHENG, Shanghai, China). Bacterial strains were grown in Columbia agar (CA) (OXOID, Basingstoke, UK) supplemented with 5\% FBS (Biological Industries, Cromwell, CT, USA) (CA-5\%FBS) and incubated under microaerobic conditions $\left(10 \% \mathrm{CO}_{2}\right.$ and $\left.5 \% \mathrm{O}_{2}\right)$ at $37^{\circ} \mathrm{C}$ for $48 \mathrm{~h}$ to $72 \mathrm{~h}$ (Thermo Scientific, Waltham, MA, USA).

To confirm the purity of cultures, verification tests were performed. In the case of Candida, Gram-staining and urease tests were performed and colonies were randomly seeded on CRHROM agar. On the other hand, for H. pylori, Gram-staining and urease, catalase and oxidase tests were made.

\subsection{Growth Curves at Different Concentrations of FBS for H. pylori and Candida Strains}

The growth curves were obtained using Brucella broth (BB) (Difco, Wokingham, UK) supplemented with different concentrations of FBS $(1 \%, 5 \%$, or $20 \%)$ or in the absence of nutrients using $0.89 \%$ saline solution (SS). To start the incubation to determine the growth curves, H. pylori and Candida strains were adjusted to an optical density (O.D.) of 0.1 at $600 \mathrm{~nm}$ at time zero. Then, $200 \mu \mathrm{L}$ of each strain suspension was placed in 96-well plates (Thomas Scientific, Swedesboro, NJ, USA) and incubated under microaerobic conditions in Infinite M200 PRO equipment (TECAN, Männedorf, Switzerland). The microaerobic condition was obtained using CampyGen sachets (Thermo Scientific, Waltham, MA, USA). The absorbance of $H$. pylori cultures was measured every $8 \mathrm{~h}$ for $72 \mathrm{~h}$, while the absorbance of yeast cultures was measured every $2 \mathrm{~h}$ for $50 \mathrm{~h}$. Absorbances were measured at $600 \mathrm{~nm}$ using the same Infinite M200 PRO equipment. All assays were performed in triplicate.

\subsection{Co-Cultures of H. pylori Strains with Candida Strains}

Individual suspensions of Candida and H. pylori strains were prepared in SS at an O.D. of 0.1 at a wavelength of $600 \mathrm{~nm}$. Four mL of BB supplemented with $1 \%, 5 \%$ or $20 \%$ FBS or $4 \mathrm{~mL}$ of SS was placed in wells of 12-well plates (Thomas Scientific, Swedesboro, NJ, USA), and then $500 \mu \mathrm{L}$ of each strain was added to each well to obtain the co-cultures. The co-cultures were incubated at $37^{\circ} \mathrm{C}$ for $48 \mathrm{~h}$ under microaerobic conditions in an incubator (Thermo Scientific, Waltham, MA, USA). Each co-culture was repeated thrice. 


\subsection{Search for Bacteria-Like Bodies (BLBs) and Culture of Yeast Cells Containing BLBs}

Fresh co-cultures were prepared as described above and $20 \mu \mathrm{L}$ aliquots were collected from each well at time 0 and then again at 1,3, 6, 12, 24, and $48 \mathrm{~h}$. Each aliquot was placed on a glass slide and observed using the 100X objective lens of an optical microscope fitted with a camera (Leica, Wetzlar, Germany). The percentage of Y-BLBs was determined after counting 200 yeast cells.

From each co-culture containing Y-BLBs, a $20 \mu \mathrm{L}$ aliquot was streaked on Sabouraud agar supplemented with chloramphenicol (SA-CHL), according to the manufacturer's instructions, and incubated at $37^{\circ} \mathrm{C}$ for $24 \mathrm{~h}$ in aerobiosis. The purpose of CHL was to eliminate extracellular H. pylori cells. At the end of the incubation period, the presence of Y-BLBs was verified observing, by optical microscopy, wet mounts from randomly selected colonies obtained on SA-CHL and the absence of extracellular bacterial contamination was confirmed using Gram-staining. Colonies were randomly selected and added to $1 \mathrm{~mL}$ of BB-5\%FBS, mixed using a vortex (DLAB, Ontario, CA, USA), $0.015 \mu \mathrm{L} / \mathrm{mL}$ clarithromycin was added and the culture was incubated under microaerobic conditions at $37^{\circ} \mathrm{C}$ for $24 \mathrm{~h}$ to eliminate any possible remaining extracellular $H$. pylori cells. After incubation, $20 \mu \mathrm{L}$ of the culture was taken and spread on SA-CHL by surface dissemination and subsequently incubated at $37{ }^{\circ} \mathrm{C}$ for $24 \mathrm{~h}$ under aerobic conditions. Colonies were reseeded 6 times in SA-CHL in order to make certain that no extra yeast bacterial cells remained in the culture medium.

\subsection{Identification of BLBs within Yeast Cells Using Fluorescent In Situ Hybridization (FISH) Technique}

Pure cultures of H. pylori J99 and C. albicans ATCC 90028 strains were used as controls. The presence of Y-BLBs was verified by means of wet mounts of yeast cells obtained from SA-CHL colonies. For the FISH technique, we modified the protocol of Böckelmann and coworkers [39]. Colonies were taken at random from Candida cultures where Y-BLBs were observed and resuspended in sterile 1X phosphate buffered saline (PBS) (Sigma-Aldrich, St. Louis, MO, USA) until reaching a turbidity similar to tube 3 of the McFarland scale. Tubes with yeast cell suspensions were centrifuged at $6700 \times g$ for 2 min (Eppendorf, San Diego, CA, USA) and the supernatant discarded; this step was repeated once more. After discarding the supernatant, a second time, 1X PBS was added to the pellet and vortexed until the entire pellet was resuspended. One hundred $\mu \mathrm{L}$ of each suspension was smeared on a slide and allowed to dry for approximately $20 \mathrm{~min}$. Once the samples were dry, they were fixed with $200 \mu \mathrm{L}$ of $37 \%$ formaldehyde solution (Sigma-Aldrich, St. Louis, MO, USA) and incubated at $4{ }^{\circ} \mathrm{C}$ in a humid chamber for $3 \mathrm{~h}$. After the formaldehyde was removed and the samples were allowed to dry at room temperature, they were incubated for 3 min each with $50 \%, 80 \%$, and $96 \%$ ethanol concentrations at room temperature. After the final incubation with ethanol, samples were allowed to dry at room temperature for approximately $15 \mathrm{~min}$. Once dry, $100 \mu \mathrm{L}$ of the hybridization solution $(270 \mu \mathrm{L}$ of $5 \mathrm{M} \mathrm{NaCl}$; $30 \mu \mathrm{L}$ of $1 \mathrm{M}$ TRIS-HCl; $525 \mu \mathrm{L}$ of $37.7 \%$ deionized formamide; $675 \mu \mathrm{L}$ of MiliQ water; and $1.5 \mu \mathrm{L}$ of $10 \%$ SDS) was added to each one of the smears followed by $6 \mu \mathrm{L}$ of the Hpy probe $5^{\prime}$-CACACCTGACTGACTATCCCG-3' labeled with Cy 3 [40] at a concentration of $5 \mathrm{ng} / \mu \mathrm{L}$. The solution was carefully mixed and incubated in a wet chamber at $46{ }^{\circ} \mathrm{C}$ to $48^{\circ} \mathrm{C}$ for $90 \mathrm{~min}$ in a thermoregulated bath (Elma, Singen, Germany) in the darkness. After hybridization, each smear was washed twice with the washing buffer $(700 \mu \mathrm{L}$ of $5 \mathrm{M} \mathrm{NaCl}, 1 \mathrm{~mL}$ of TRIS- $\mathrm{HCl}, 48.25 \mathrm{~mL}$ of sterile distilled water and $50 \mu \mathrm{L}$ of $10 \%$ SDS). One $\mathrm{mL}$ of buffer was used per wash and it was left to incubate in a humid chamber in a thermoregulated bath at $46^{\circ} \mathrm{C}$ to $48^{\circ} \mathrm{C}$ for $20 \mathrm{~min}$ the first time and $5 \mathrm{~min}$ the second time, discarding the remaining buffer each time. Then, it was allowed to dry and $200 \mu \mathrm{L}$ of 1:10 aniline blue in 1X PBS (both Sigma-Aldrich, St. Louis, MO, USA) was added and incubated for $10 \mathrm{~min}$. Subsequently, it was washed 2 times with $1 \mathrm{~mL}$ of $1 X$ PBS each time, allowing it to dry at room temperature in the dark. Finally, the samples were observed in a fluorescence microscope (Motic, Viking Way, Richmond, BC, Canada) fitted with the 
FITC (AT480/535) and TRIC (AT540/605) filters. The images were processed using ImageJ software version 1.53 (NIH Image, Bethesda, MD, USA) to combine the images obtained with the Merged filters.

\subsection{Detection of H. pylori $16 S$ rRNA}

This assay was performed using $24 \mathrm{~h}$ old cultures in SA medium where the presence of Y-BLBs was observed. Yeast cells were resuspended in $1 \mathrm{~mL}$ of SS at an O.D. of 0.1 at $600 \mathrm{~nm}$ and centrifuged at $6700 \times \mathrm{g}$ for $2 \mathrm{~min}$ (Eppendorf, San Diego, CA, USA). The pellet was resuspended in $1 \mathrm{~mL}$ of $10 \mathrm{mM}$ Tris EDTA buffer (TE) pH 8.0, vortexed for $5 \mathrm{~s}$ (DLAB, Ontario, CA, USA), centrifuged at 11,300 $\times g$ for $5 \mathrm{~min}$ (Eppendorf, San Diego, CA, USA), and the supernatant discarded. In $200 \mu \mathrm{L}$ of TE buffer, a suspension at an O.D. of 0.1 at $600 \mathrm{~nm}$ was obtained and a heat shock was performed by freezing at $-80{ }^{\circ} \mathrm{C}$ for $30 \mathrm{~min}$ followed by thawing in a thermoblock at $100{ }^{\circ} \mathrm{C}$ for $10 \mathrm{~min}$. Three cycles were carried out under these conditions. After the last cycle, the tubes were incubated at $-80^{\circ} \mathrm{C}$ for $24 \mathrm{~h}$. The next day, the samples were incubated at $70{ }^{\circ} \mathrm{C}$ for $2 \mathrm{~h}$ and the total DNA extracted using the commercial NucleoSpin Tissue kit (MACHEREY-NAGEL, Düren, Germany), as per manufacturer's instructions. After total DNA extraction, amplification of the H. pylori 16S rRNA gene was performed according to Sánchez-Alonzo et al. [38]. Twelve and a half $\mathrm{mL}$ of the master mix, $1 \mu \mathrm{L}$ of primers F-5'CTCGAGAGACTAAGCCCTCC $3^{\prime}$ R-5' ${ }^{\prime}$ ATTACTGACGCTGATGTGC3, $5.5 \mu \mathrm{L}$ of PCR grade water, and $1.5 \mu \mathrm{L}$ of DNA sample. Thirty amplification cycles were programmed in a thermocycler (Eppendorf, San Diego, CA, USA), which included cycles for initial denaturation temperature at $94{ }^{\circ} \mathrm{C} / 1 \mathrm{~min}$, denaturation temperature at $98{ }^{\circ} \mathrm{C} / 30 \mathrm{~s}$, hybridization temperature at $53{ }^{\circ} \mathrm{C} / 5 \mathrm{~s}$, extension temperature at $72^{\circ} \mathrm{C} / 40 \mathrm{~s}$ and a final extension temperature at $72{ }^{\circ} \mathrm{C} / 10 \mathrm{~min}$. Electrophoresis was performed in $2 \%$ agarose gel (Lonza, Walkersville, MD, USA) plus $1 \mu \mathrm{L}$ of GelRed (Biotium, Landing Parkway, Fremont, CA, USA). Five $\mu \mathrm{L}$ of amplified product and $1 \mu \mathrm{L}$ of molecular weight markers were added to each well of the gel in a separate well. The gel was run at $70 \mathrm{~V}$ for $90 \mathrm{~min}$. Subsequently, the amplicons were visualized by exposing the gel to ultraviolet light in the ENDURO model photo documenter (Labnet, Edison, NJ, USA).

\subsection{Cell Viability Assay}

This assay was performed to confirm the viability of $H$. pylori inside the yeast vacuoles. Aliquots of bacteria suspensions containing Y-BLBs were stained with a solution of LIVE/DEAD BacLight Bacterial Viability kit L-7012 (ThermoFisher, Waltham, MA, USA) and incubated for $15 \mathrm{~min}$ in darkness. After incubation, the tubes were vortexed (DLAB, Ontario, CA, USA) at its minimal speed for $3 \mathrm{~s}$. Ten $\mu \mathrm{L}$ of the suspension were added to each slide and a coverslip added to visualize each sample under the 100X objective lens of a fluorescence microscope fitted with a camera (Motic, Viking Way, Richmond, BC, Canada). The FITC (AT480/535) and TRIC filters (AT540/605) were used. Images were obtained, processed using ImageJ software (NIH Image, Bethesda, MD, USA) and superimposed to create merged images.

\subsection{Statistical Analysis}

Data were processed using the SPSS 24.0 software (IBM Company, Armonk, NY, USA). Tukey's test was applied to determine the presence of statistically significant differences. Values of $p \leq 0.05$ were considered significant and values $p \leq 0.0001$ were considered highly significant. According to the results of Tukey's test, data shown in tables or figures sharing the same letter are not significantly different.

\section{Results}

\subsection{Strain Cultures}

Cultures of $H$. pylori strains were grown in CA-5\%FBS until the typical morphology of colonies was obtained, showing small, translucent, colorless, convex-shaped bacterial 
colonies (Figure 1A). Gram-negative bacilli were observed after a Gram-stain (Figure 1B). Enzymatic activity tests detected the enzymes urease, catalase, and oxidase (Figure 1C-E). Figure 2 depicts the culture and confirmation of yeast purity on SA-CHL, where the growth of whitish, creamy, convex colonies was observed (Figure 2A). The Gram-stain (Figure 2B) showed the typical yeast-like morphology of Candida and the absence of extracellular bacteria that could be contaminating the fungal culture. Figure $2 \mathrm{C}$ shows a wet mount of yeast cells whose vacuoles lack BLBs (arrows). Lastly, Figure 2D shows a negative result for the urease test, confirming the absence of $H$. pylori.

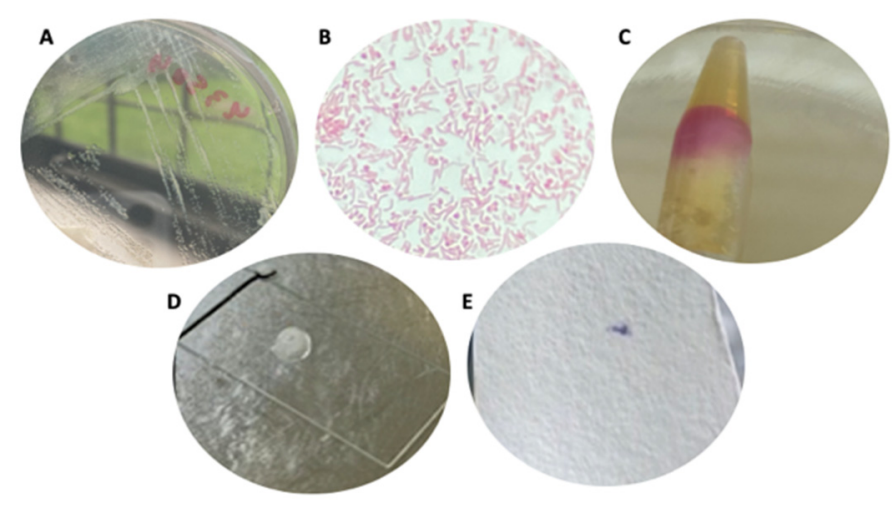

Figure 1. Typical culture and microbiological identification of H. pylori. (A) Culture of H. pylori in CA5\%FBS; (B) Gram-stained smear; (C) Urease test; (D) Catalase test; and (E) Oxidase test. CA-5\%FBS: Columbia agar supplemented with $5 \%$ FBS.

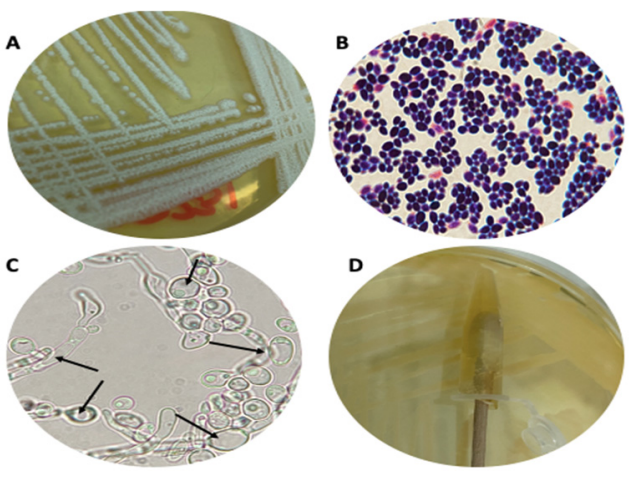

Figure 2. Culture and purity verification of Candida ATCC 90030 strain as representative of the strains used in the present work. (A) Yeast culture on Sabouraud agar; (B) Gram-stain of yeast cells; (C) Wet mount of yeast cells obtained from pure cultures. Note the vacuoles of yeast cells (black arrows) lacking BLBs; (D) Urease test performed on yeast cultures. BLBs: bacteria-like bodies.

\subsection{Growth Curves of the Different Strains of H. pylori and Candida at Varying FBS} Concentrations or SS

The growth obtained in $H$. pylori strains was directly affected by a low percentage of FBS or its replacement by SS. No significant growth differences were observed in the presence of $5 \%$ or $20 \%$ FBS, reaching the exponential growth phase from approximately $16 \mathrm{~h}$ to $56 \mathrm{~h}$. No growth was observed in the presence of $1 \%$ FBS or SS-only (Figure 3). 

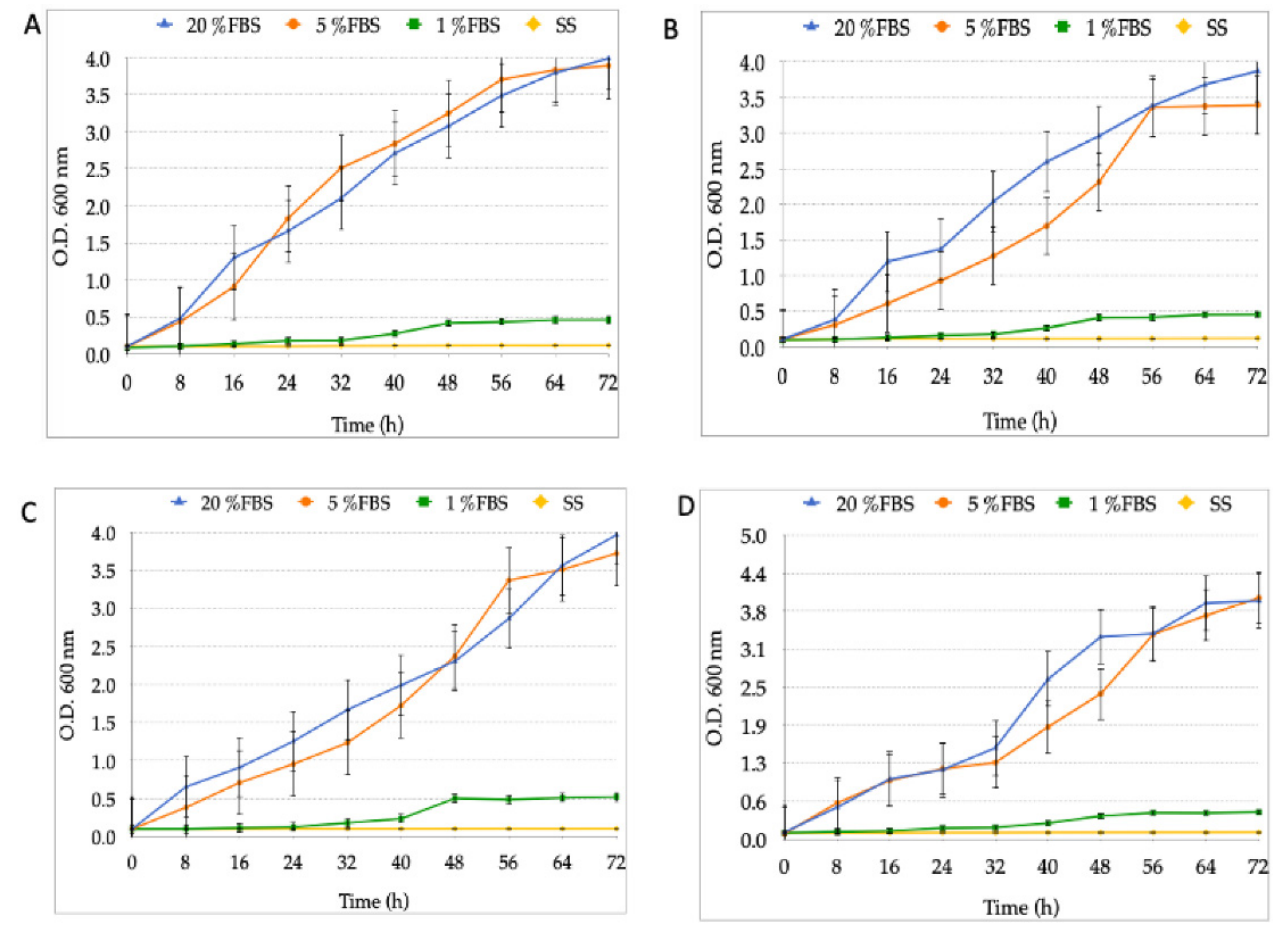

Figure 3. Growth curves of different $H$. pylori strains in the presence of BB supplemented with $1 \%$, $5 \%$ or $20 \%$ FBS or SS. (A) H. pylori J99; (B) H. pylori G-27; (C) H. pylori SS1 and (D) H. pylori H707. BB: Brucella broth; FBS: fetal bovine serum; SS: saline solution.

Candida grew in BB supplemented with $1 \%, 5 \%$ or $20 \%$ FBS and SS. A more pronounced growth curve was observed in the culture supplemented with $20 \%$ FBS. No significant differences were observed when comparing the growth curves in the presence of $1 \%$ or $5 \%$ FBS. Yeast strains quickly reached a stationary phase in the presence of SS-only cultures (Figure 4).

\subsection{Search for BLBs within Yeasts of the Genus Candida}

In wet mounts of $\mathrm{H}$. pylori-Candida co-cultures observed using the 100X objective lens of an optical microscope, the presence of BLBs within the vacuoles of yeast (Figure 5A, black arrows) was detected. The movement of BLBs within the vacuoles is shown in Video S1. In addition, we observed an accumulation of coccoid and bacillary bacteria on the yeast pseudohyphae previously co-cultured with H. pylori cells (Figure 5A, red arrow). Cells from a pure Candida culture showed, as expected, the absence of BLBs (Figure 5B).

When counting the Y-BLBs in the different co-cultures in BB supplemented with $1 \%$, $5 \%$ or $20 \%$ FBS, the highest percentage of Y-BLBs (53\% to $60 \%$ ) was obtained in the cocultures where $1 \%$ FBS was used, followed by co-cultures supplemented with $5 \%$ and $20 \%$ FBS (22\% to $26 \%$ and $7 \%$ to $12 \%$, respectively) (Figure 6). On the other hand, the lowest Y-BLBs percentages were observed in the co-cultures incubated in SS-only (Figure 6). 

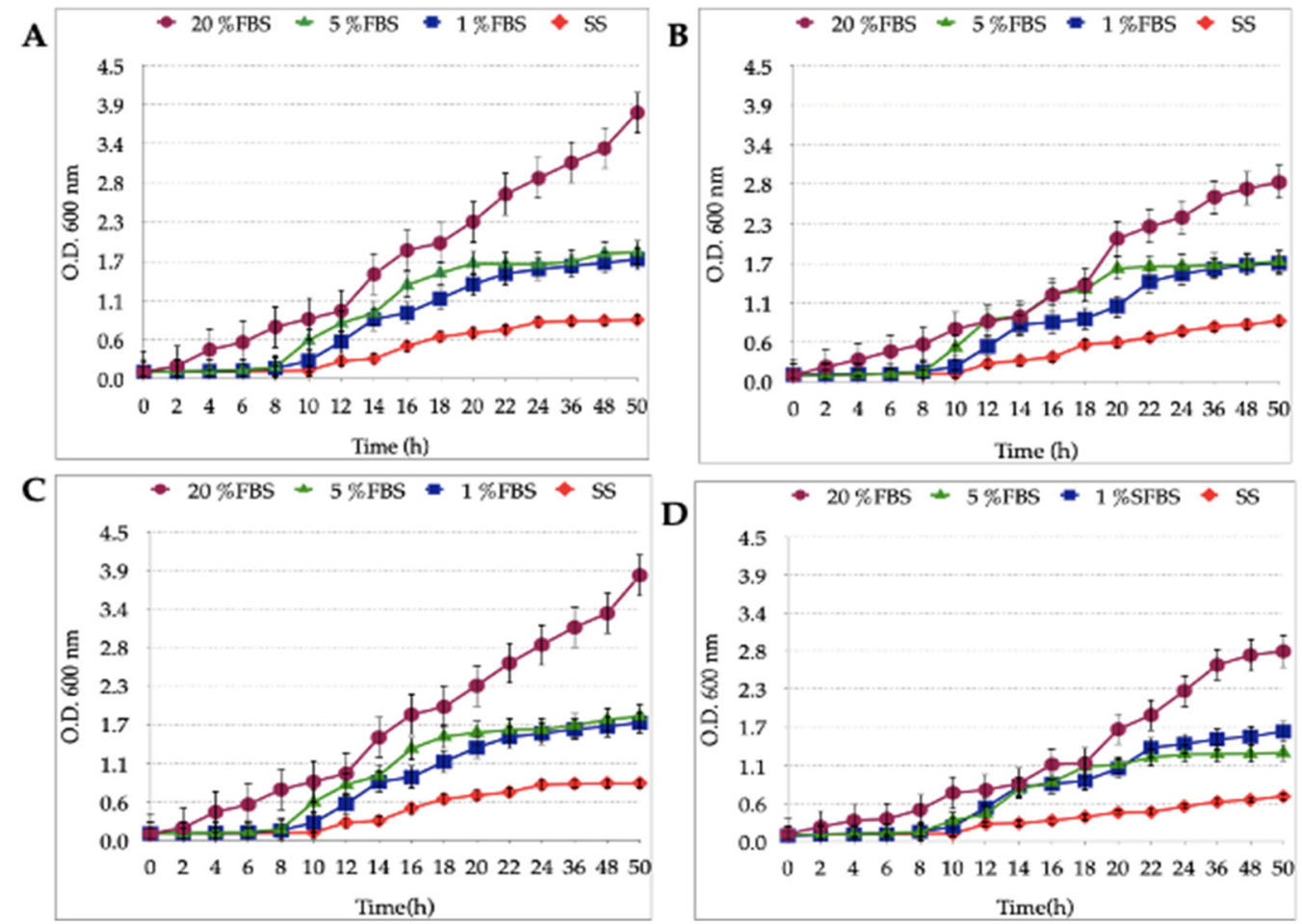

Figure 4. Candida growth curves in the presence of BB supplemented with $1 \%, 5 \%$ or $20 \%$ FBS or its absence. (A) C. albicans ATCC 90028; (B) C. glabrata ATCC 90030; (C) C. albicans VT-3; (D) C. glabrata LEO-37. The highest growth level was achieved using $20 \%$ FBS, followed by the cultures with $1 \%$ and 5\% FBS. In the latter, there was no significant difference identified between these two growth curves $p>0.05$; however, a highly significant difference was found between the growth curves in SS when compared with the other treatments $p<0.0001$.
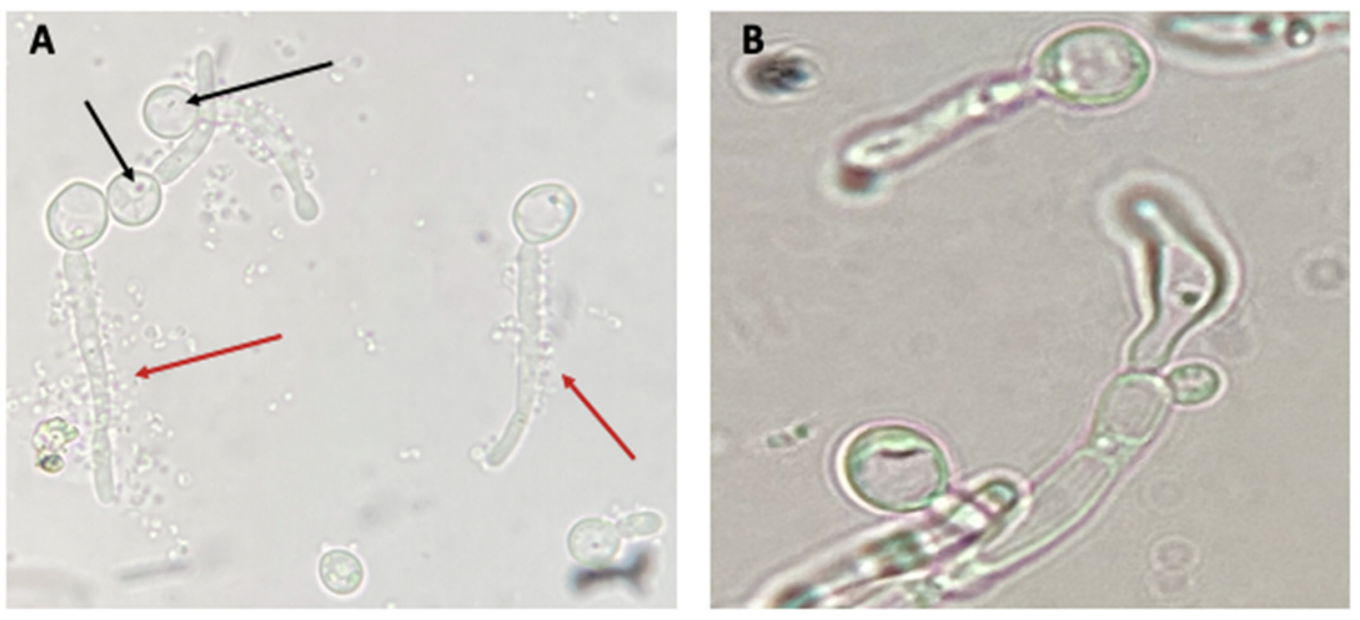

Figure 5. (A) Wet mount of H. pylori H707-C. albicans VT-3 24 h co-culture in BB-1\%FBS showing Y-BLBs (black arrows) and H. pylori cells attached to pseudohyphae (red arrows). (B) Wet mount of C. albicans VT-3 cells from a pure culture (negative control) showing the absence of Y-BLBs. Movement of BLBs within yeasts is shown in Video S1. BB-1\%FBS: Brucella broth supplemented with $1 \%$ of fetal bovine serum. 


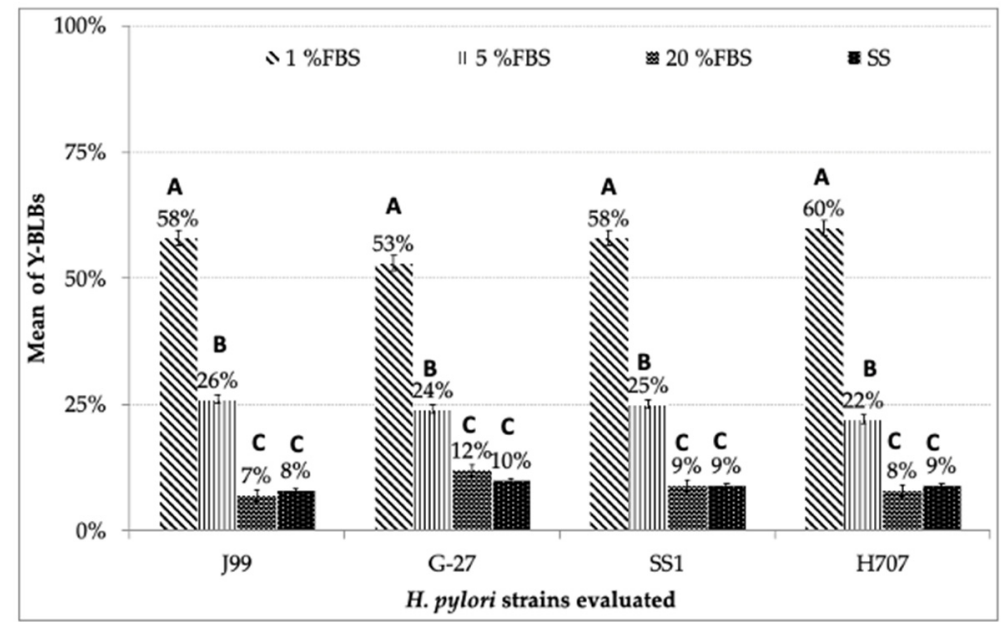

Figure 6. Mean percentage of Y-BLBs when H. pylori and Candida spp. were co-cultured in BB supplemented with $1 \%, 5 \%$ or $20 \%$ FBS concentrations or in SS. Mean percentages of Y-BLBs remained above $50 \%$ in the co-cultures supplemented with $1 \%$ FBS. No significant differences were observed between the percentages of Y-BLBs obtained in the co-cultures evaluating the same strains of $H$. pylori in the presence of different FBS concentrations. Different letters indicate significant differences $(p<0.05)$.

Subsequently, in order to analyze the interaction of the different strains of Candida and $H$. pylori when co-cultured, the time at which the highest Y-BLBs mean was obtained in each co-culture supplemented with the different FBS concentrations was determined (Figure 7). Once the times with the highest percentages of mean Y-BLBs were obtained, the data were analyzed using Tukey's test to determine if any differences were dependent on the type of bacterial or fungal strains or only on the concentration of FBS. The analysis showed that the most important factor generating the intracellular interaction between H. pylori and Candida was the concentration of FBS in the medium. However, in all the co-culture conditions, higher means were observed between H. pylori strains $\mathrm{H707}$ and J99 with C. glabrata ATCC90030 and LEO-37 strains (Figure 8). The interaction of all co-cultures is shown in Figures S1-S3.

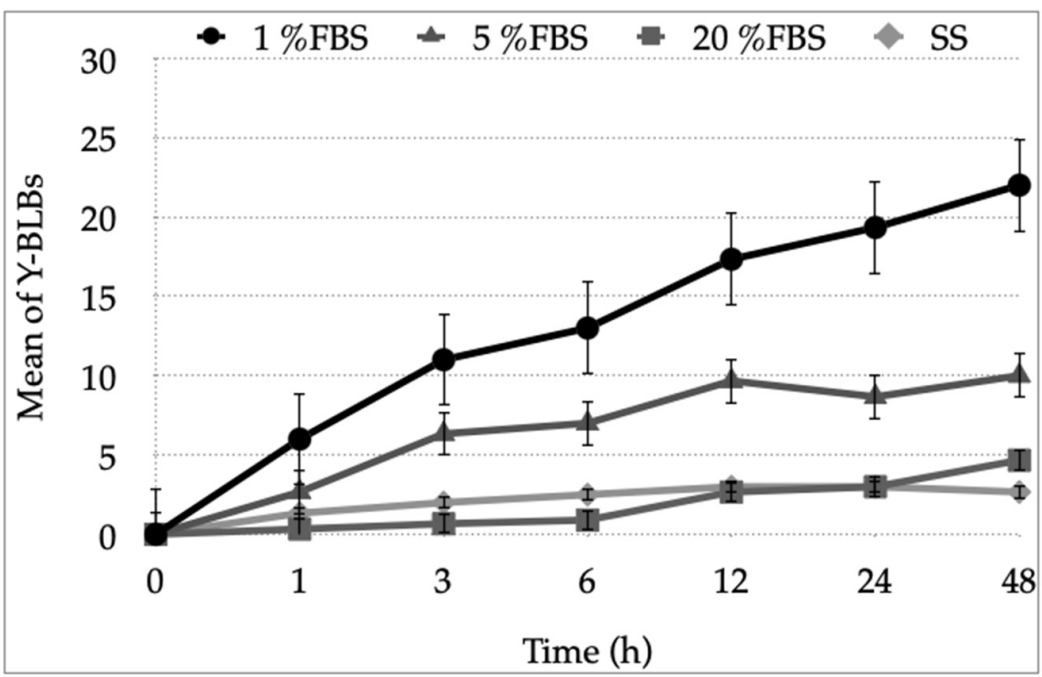

Figure 7. Means of Y-BLBs were obtained for all bacterial strain and yeast strain combinations cultured in BB supplemented with $1 \%, 5 \%$ or $20 \%$ FBS or SS during $48 \mathrm{~h}$. This figure shows the means of Y-BLBs obtained when co-culturing H. pylori J99 and C. glabrata ATCC 90030 strains. The higher means of Y-BLBs for this bacteria-yeast combination were observed at $24 \mathrm{~h}$ and $48 \mathrm{~h}$. Culture medium supplemented with $1 \%$ or $5 \%$ FBS produced the higher means of yeast cells harboring bacteria. 


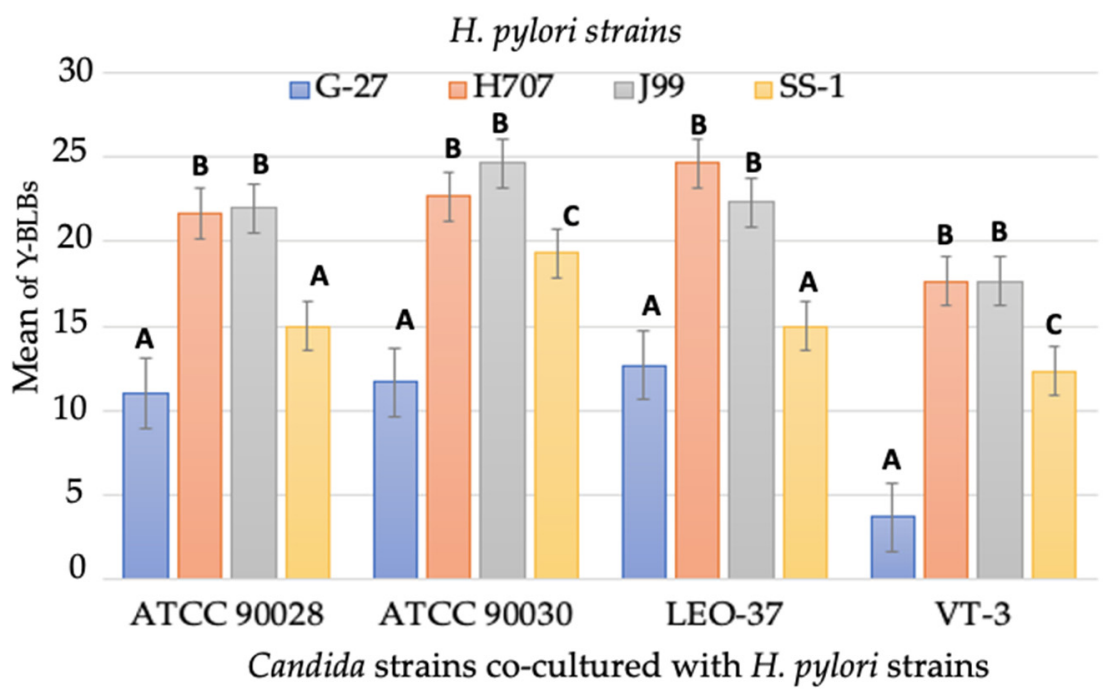

Figure 8. Mean of Y-BLBs identified in the co-cultures incubated in BB-1\%FBS for $48 \mathrm{~h}$. There is no significant difference in Y-BLB means when comparing co-cultures carried out with $H$. pylori J99 or H707 strains with all yeast strains. The higher means of Y-BLBs were obtained in the co-cultures carried out with these two strains and the two C. glabrata strains. Results are expressed as mean \pm SD. Means with different letters are significantly different $(p<0.05)$.

\subsection{Identification of BLBs in Yeast Using the Fluorescent In Situ Hybridization (FISH) Technique}

To identify the mobile BLBs harbored within the vacuoles of yeast cells, the FISH technique, combined with a specific probe, labeled with $\mathrm{Cy} 3$ fluorochrome, for $\mathrm{H}$. pylori was used. This assay showed the expected red fluorescence confirming that BLBs harbored within yeast cells were, in fact, $H$. pylori (Figure 9A). When this technique was performed in yeast cells obtained from a pure culture, there was no hybridization of the probe specific for H. pylori (Figure 9B), but the hybridization took place when testing cells from a pure H. pylori culture (Figure 9C).
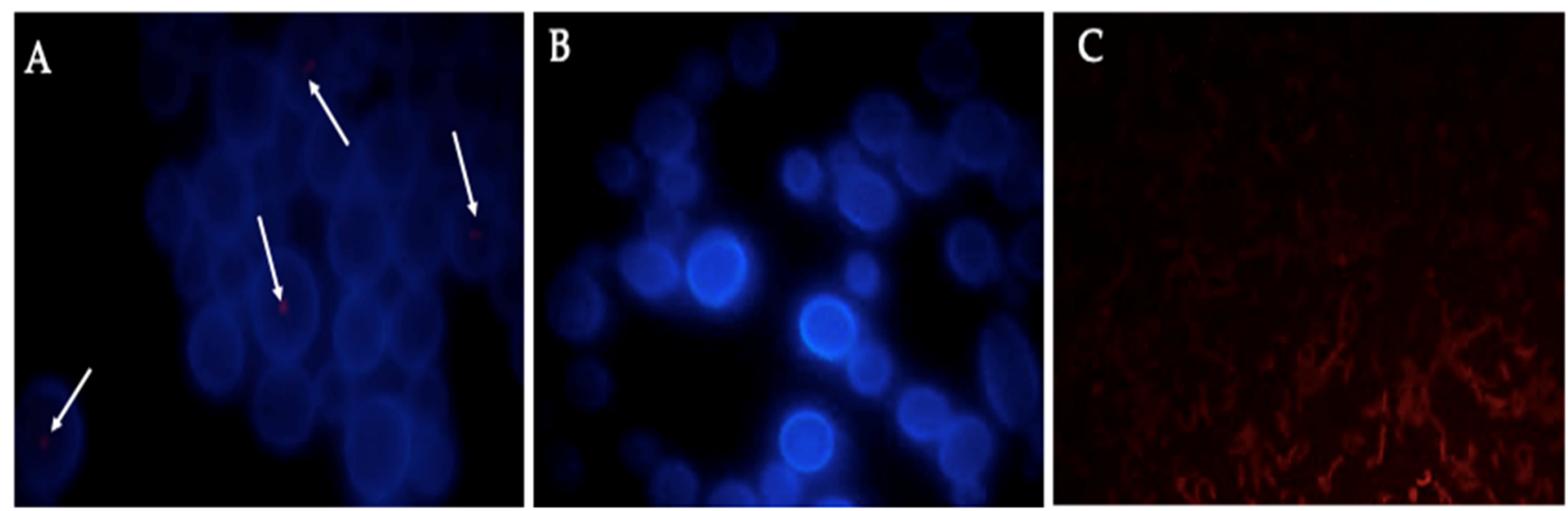

Figure 9. Images showing the results of FISH analysis using a fluorescent probe specific for H. pylori. Yeast cells obtained from a H. pylori G-27-C. glabrata ATCC 90030 strain co-cultured in BB-5\%FBS. (A) Hybridization of the H. pylori specific probe within C. glabrata ATCC 90030 cells (white arrows); (B) C. glabrata ATCC 90030 from a pure culture (negative control) showing the absence of hybridization of the fluorescent probe; (C) Pure H. pylori G27 strain used as positive control (red fluorescence). Blue fluorescence corresponds to the binding of aniline blue to $1-3 \mathcal{B}$-glucans of yeast cells. BB-5\%FBS: Brucella broth supplemented with 5\% FBS. 


\subsection{Detection of H. pylori $16 S$ rRNA Gene}

Figure 10 shows the amplification of the $16 \mathrm{~S} r R N A$ gene of $H$. pylori in total yeast DNA extracted after incubating a $H$. pylori-C. glabrata strains co-culture during $48 \mathrm{~h}$. The expected amplicon, with a size of $110 \mathrm{bp}$, was observed in the lanes corresponding to DNA extracted from yeast cells previously co-incubated with the bacterium. The absence of amplification in the lane of the negative control (DNA of pure C. glabrata ATCC 90030) and the blank (water grade PCR, master mix and primers) confirmed that there was no H. pylori contamination of the yeast strains nor of the reagents used.
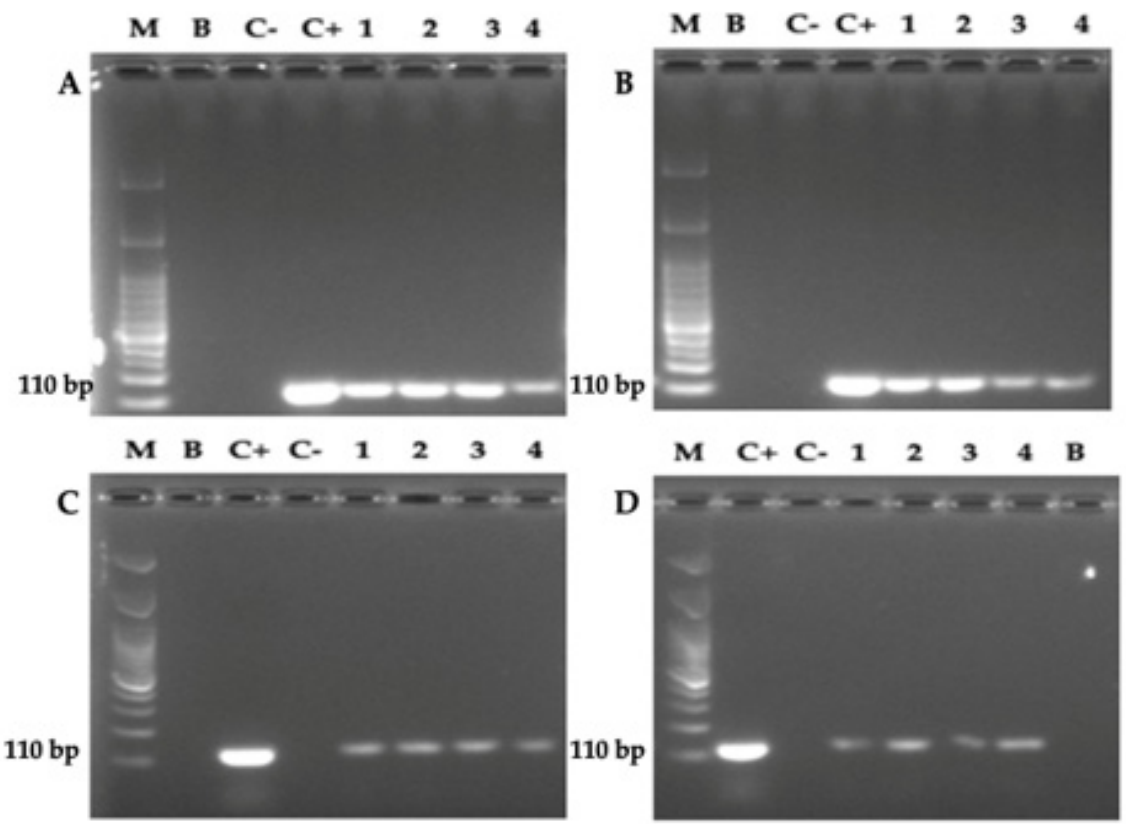

lane 1: H. pylori J99-C. albicans ATCC 90028;

lane 2: H. pylori J99-C. glabrata ATCC 90030;

lane 3: H. pylori J99-C. albicans VT-3;

lane 4: H. pylori J99-C. glabrata LEO-37

Figure 10. Image of a $2 \%$ agarose gel showing the amplicons obtained after amplifying the $H$. pylori $16 S$ rRNA gene from total DNA extracted from Candida cells co-cultured with the different strains of $H$. pylori cultured in BB supplemented with $1 \%, 5 \%$ or $20 \%$ FBS or in SS. M: molecular weight markers, B: blank (master mix, primers, PCR grade water), C-: negative control (DNA from pure C. glabrata ATCC 90030), C+: positive control (DNA from pure H. pylori J99). Lanes 1-4 correspond to the amplicons obtained from DNA extracted from yeasts co-cultured with H. pylori. (A) Co-cultures in BB-1\%FBS; (B) co-cultures in BB-5\%FBS; (C) co-cultures in BB-20\%FBS; (D) co-cultures in SS.

\subsection{Cell Viability Assay}

After confirming, using FISH and PCR, that BLBs harboring within yeast cells belong to the H. pylori species, the viability of intra-yeast bacteria was tested using the LIVE/DEAD BacLigh Bacterial Viability kit. The green fluorescence observed within the vacuole of yeast cells indicates that $H$. pylori cells retained their viability once inside the yeast cells (Figure 11). In addition, the mobility of the bacteria within the yeast vacuole can be inferred by their change in position in time-lapse photography at $1 \mathrm{~s}$ intervals (Figure 11). 


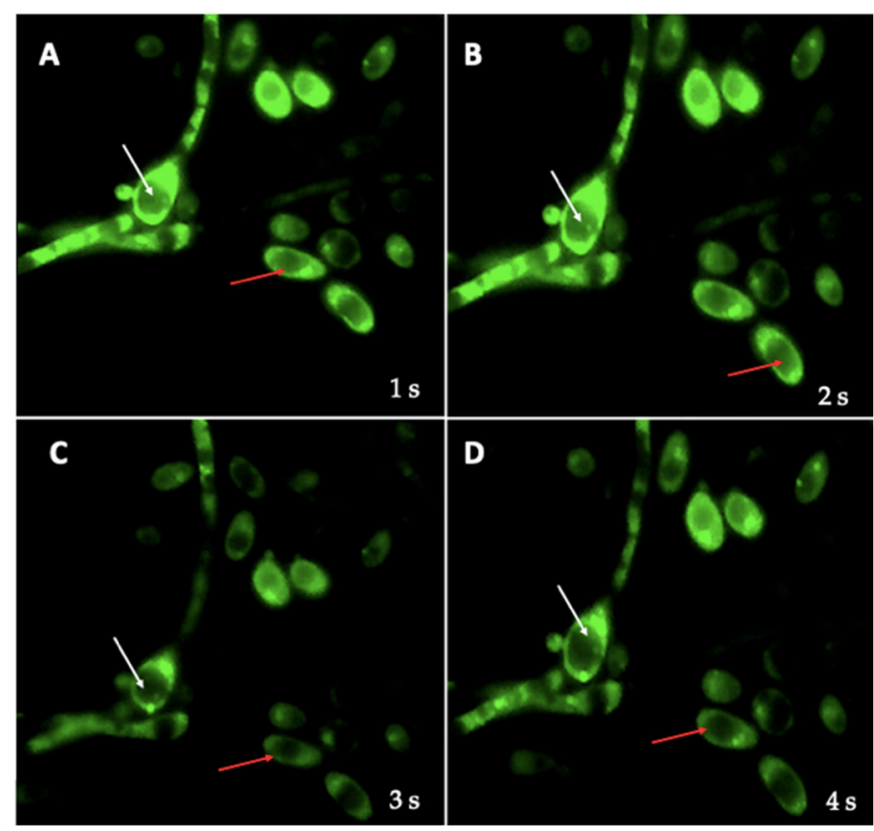

Figure 11. A, B, C and D correspond to a same microscopic field photographed at $1 \mathrm{~s}$ intervals. Cell viability, indicated by green fluorescence, of $H$. pylori harbored within C. albicans VT-3 after co-culturing them during $48 \mathrm{~h}$. White arrows indicate yeast cells harboring intravacuolar H. pylori. The change in the position of $H$. pylori, at $1 \mathrm{~s}$ intervals, within the yeast can be observed (white arrow). In addition, the figure also shows yeast cells lacking intracellular H. pylori (red arrows).

\section{Discussion}

H. pylori is a pathogen adapted to colonize the stomach, an anatomical site rich in nutrients, including minerals such as iron [41]. These nutritional conditions are not so easy to replicate in the culture media used in the laboratory; hence, this bacterium is considered fastidious to culture. Since it contains hemoglobin, cholesterol, proteins and other factors required by $H$. pylori to grow, FBS supplementation of the culture media used for the isolation of this microorganism is an excellent option as a source of nutrients that favors the in vitro growth of this bacterium [12,15].

In this work, it was observed that the growth of H. pylori in BB-20\%FBS was not significantly different when compared to the bacterial growth obtained using $5 \%$ FBS. One of the most abundant components in FBS is iron, and although it is an important growth factor for many organisms, including H. pylori, it can also be toxic at high concentrations [13,41]. During digestion, the human stomach, where H. pylori naturally resides, is subjected to changes in iron concentration [42].

This pathogen can be found in the gastric mucus, adhered to the gastric epithelium or located intracellularly in the epithelial cells $[43,44]$, locations where iron availability is scarce. When there are high iron concentrations in its environment, $H$. pylori can control the uptake mechanisms of this chemical element, making use of the iron-sensitive protein family known as ferric uptake regulator (FUR). This protein family (which includes FecA1, FecA2, FrpB1, and FeoB) regulates the bacteria's iron uptake systems, acting as iron transporters. When iron intracellular levels are low, FUR cannot bind to the Fur box's sequences, considerably increasing the transcription of genes associated with extracellular iron uptake. This increases the exchange of extra and intracellular iron from the host and vice versa [16].

The lack of growth when H. pylori was cultured either in BB-1\%FBS or in SS was expected because this bacterium typically requires $5 \%$ to $10 \%$ FBS [12,15,45]. Consequently, the lack of a nutritious culture medium and the absence of FBS as seen in SS cultures were unfavorable growth conditions for H. pylori. These findings are supported by prior reports indicating that bacteria under nutritional stress generate a characteristic response that 
involves the rapid accumulation of guanosine tetraphosphate (ppGpp) and the inhibition of stable RNA synthesis; therefore, bacteria enter a stationary growth phase. This is also true for H. pylori under starvation conditions $[45,46]$. The growth curves reported in this study are similar to those reported in the literature where, under starvation conditions, the SpoT protein restricts bacterial growth but cells maintain their helical shape $[45,46]$.

The Candida strains analyzed in the present work grew in all FBS concentrations tested, and overgrowth was observed using BB-20\%FBS. The growth observed in SS was significantly lower when compared to the curves obtained when Candida strains were incubated in FBS-supplemented culture medium. It has been described that yeasts have an excellent capacity to adapt to changes in the environment, and under starvation conditions Candida is capable of forming biofilms to survive, but not to replicate $[47,48]$. The results obtained in this study, when Candida strains were cultured in SS, are similar to those of Delgado and coworkers [49]. On the other hand, like H. pylori, yeasts have specialized machinery to regulate iron uptake when this element is in high or low extracellular concentration [50].

The first Y-BLBs were identified during the first hour of co-culturing both microorganisms. The maximum percentage of Y-BLBs was observed at $24 \mathrm{~h}$ and $48 \mathrm{~h}$ in all co-cultures, but the mean of Y-BLBs obtained in the co-culture containing BB-1\%FBS was significantly higher than that obtained in the other culture conditions. When analyzing the percentages of Y-BLBs, the figures were more than $50 \%$ in BB-1\%FBS, between $22 \%$ and $26 \%$ in BB- $5 \% \mathrm{FBS}, 7 \%$ to $12 \%$ in BB- $20 \% \mathrm{FBS}$, and $9 \%$ in co-cultures carried out in SS. Therefore, the percentages of Y-BLBs increased as the concentration of FBS decreased. This may be due to the stressing conditions sensed by $H$. pylori that threaten its viability. On the contrary, these culture conditions offered Candida all the nutrients necessary for its growth, providing protection for $\mathrm{H}$. pylori cells capable of harboring within yeast cells. Interestingly, we identified extracellular bacteria that adhered to the pseudohyphae of yeasts, which may be due to the adhesins present on the surface of this fungal structure.

Regarding this last observation, the adherence of H. pylori cells to several species of the Candida genus was first reported by Ansorg and Schmid [51]. The adherence of several bacteria to the surface of fungi has been reported and, in the particular case of Candida, it has been reported for Staphylococcus aureus, Group B Streptococcus, Staphylococcus epidermidis and Streptococcus gordonii, among others, perhaps promoting the dissemination of bacteria throughout the host [52-55]. Regarding the internalization of H. pylori in a human cell model, it has been reported that it occurs most often in ulcer-related samples [56]. It is worth noting that the H. pylori strain showing the best capacity to harbor within Candida was the J99 strain, whose genotype is related to the development of duodenal ulcers. Another work reported the presence of a link between the coexistence of H. pylori and Candida and gastric ulcers, suggesting the synergism of these microorganisms in the pathogenicity of this disease [57].

Considering that both BB-1\%FBS and SS are poor in nutrients, it was possible to anticipate that co-cultures in SS might show a percentage of Y-BLBs similar to that of BB$1 \%$ FBS, but this was not the case. In fact, the percentage of Y-BLBs in SS was not significantly different to that observed in the co-culture in BB-20\%FBS. The absence of nutrients in SS might negatively affect the mobility of $\mathrm{H}$. pylori and favor the development of its coccoid stage (immobile) [58]. Although yeast cells were also in the absence of nutrients, they can survive under inanition and modulate their highly dynamic cell wall according to the conditions to which they are subjected [59]. In yeasts such as C. glabrata and C. albicans, starvation promotes the migration of cytolytic proteins, and they can alter the expression of cell wall proteins. This leads to cell impermeability, adhesion, and the formation of biofilms to survive under stress conditions [49]. In addition, during starvation and other stress conditions that affect $C$. albicans, the chlamydosporulation process is triggered, promoting the generation of chlamydospores, which are cells with a much thicker cell wall, which would make the entry of $H$. pylori difficult [60]. In addition, the loss of mobility and of bacterial viability can explain the low percentage of Y-BLBs found in SS co-cultures. On the contrary, in the abundance of FBS, both microorganisms were not under stress and, 
therefore, $H$. pylori was not induced to seek refuge within yeast cells, but a baseline entry occurred anyways.

The identification of BLBs as H. pylori was performed using both FISH and PCR techniques. Furthermore, the LIVE/DEAD BacLight Bacterial Viability kit allowed us to confirm the viability of $H$. pylori within fungal cells. These results are similar to our previous works subjecting $H$. pylori cells to other stressing conditions $[30,35]$ and reports by Siavoshi et al. $[30,61]$.

Lastly, we investigated if the endosymbiotic interaction between different $H$. pylori and Candida strains was strain dependent. Although there was no significant difference between the means of Y-BLBs obtained by the different strains in the same co-culture conditions, the higher means observed were between C. glabrata (ATCC 90030 and LEO-37) strains and H. pylori J99 and H707 strains. At the present time, there are still no reports that allow us to comment on the behavior between strains. However, it has been reported that under starvation, C. glabrata expresses adhesion cell wall proteins and also that this species possesses a higher percentage of mannoproteins when compared to C. albicans. The above could be the basis for future research to answer this question.

\section{Conclusions}

The results of $H$. pylori and Candida co-cultures demonstrated that nutrient deficiency (using FBS as a supplement of nutrients model) is a stressor for H. pylori, which significantly increased its entry into Candida cells. Furthermore, under starvation of both H. pylori and Candida strains, the percentages of Y-BLBs decreased significantly, suggesting that starving yeast cells may be less capable of harboring stressed H. pylori cells. The results obtained in this study also highlight that the endosymbiotic relationship between $\mathrm{H}$. pylori and Candida is dependent on the bacterial strains. Therefore, based on the results obtained in this study, it can be inferred that yeast cells may contribute to the subsistence of this pathogenic bacterium when subjected to nutrient deficiency until it may infect an appropriate host, such as humans.

Supplementary Materials: The following are available online at https://www.mdpi.com/article/ 10.3390/biology10050426/s1. Figure S1: Co-cultures of H. pylori strains with Candida strains in BB$20 \% \mathrm{FBS}$ at $37^{\circ} \mathrm{C} / 48 \mathrm{~h}$; Figure S2: Co-cultures of $\mathrm{H}$. pylori strains with Candida strains in BB-5\%FBS at $37^{\circ} \mathrm{C} / 48$ h; Figure S3: Co-cultures of $\mathrm{H}$. pylori strains with Candida strains in $\mathrm{BB}-5 \% \mathrm{FBS}$ at $37^{\circ} \mathrm{C} / 48 \mathrm{~h}$; Video S1: Wet mount observed using an optical microscope of a H. pylori-Candida co-culture showing mobile bacteria-like bodies within the vacuole of yeast cells.

Author Contributions: Conceptualization, K.S.-A. and A.G.-C.; methodology. K.S.-A., C.P.-S., A.G.C.; validation, K.S.-A., F.S.-M., L.A.-A., C.P.-S., H.B., V.L.C., C.T.S., A.G.-C.; formal analysis, K.S.-A., H.B., F.S.-M., L.A.-A.; investigation, K.S.-A., C.P.-S., A.G.-C.; resources, H.B., A.G.-C.; data curation, K.S.-A., H.B., writing—original draft preparation, K.S.-A., F.S.-M., L.A.-A., H.B., C.T.S., A.G.-C.; writing-review and editing, K.S.-A., F.S.-M., L.A.-A., C.P.-S., H.B., V.L.C., C.T.S., A.G.-C.; visualization, K.S.-A., F.S.-M., L.A.-A., C.P.-S., H.B., V.L.C.; supervision, A.G.-C.; project administration, A.G.-C.; funding acquisition, A.G.-C. All authors have read and agreed to the published version of the manuscript.

Funding: This work was supported by Grant VRID-Enlace 218.036.047-1.0, University of Concepcion, Concepcion, Chile.

Institutional Review Board Statement: Not applicable.

Informed Consent Statement: Not applicable.

Acknowledgments: The collaboration and support of Laboratorio Pasteur.

Conflicts of Interest: The authors declare no conflict of interest. 


\section{References}

1. Burucoa, C.; Axon, A. Epidemiology of Helicobacter pylori infection. Helicobacter 2017, 22 (Suppl. S1), e12403. [CrossRef]

2. Sjomina, O.; Pavlova, J.; Niv, Y.; Leja, M. Epidemiology of Helicobacter pylori infection. Helicobacter 2018, 23 (Suppl. S1), e12514. [CrossRef]

3. Sachs, G.; Scott, D. Helicobacter pylori: Eradication or Preservation. F1000 Med. Rep. 2012, 4, 7. [CrossRef] [PubMed]

4. Den Hollander, W.J.; Holster, I.L.; den Hoed, C.M.; Capelle, L.G.; Tang, T.J.; Anten, M.-P.; Prytz-Berset, I.; Witteman, E.M.; ter Borg, F.; Hartog, G.d.; et al. Surveillance of premalignant gastric lesions: A multicentre prospective cohort study from low incidence regions. Gut 2019, 68, 585. [CrossRef] [PubMed]

5. Banks, M.; Graham, D.; Jansen, M.; Gotoda, T.; Coda, S.; di Pietro, M.; Uedo, N.; Bhandari, P.; Pritchard, D.M.; Kuipers, E.J.; et al. British Society of Gastroenterology guidelines on the diagnosis and management of patients at risk of gastric adenocarcinoma. Gut 2019, 68, 1545-1575. [CrossRef]

6. Schistosomes, I.A.R.C. Liver flukes and Helicobacter pylori. IARC Working Group on the Evaluation of Carcinogenic Risks to Humans. Lyon, 7-14 June 1994. IARC Monogr. Eval. Carcinog. Risks Hum. 1994, 61, 1-241.

7. Malfertheiner, P.; Megraud, F.; O’Morain, C.A.; Gisbert, J.P.; Kuipers, E.J.; Axon, A.T.; Bazzoli, F.; Gasbarrini, A.; Atherton, J.; Graham, D.Y.; et al. Management of Helicobacter pylori infection-the Maastricht V/Florence Consensus Report. Gut 2017, 66, 6-30. [CrossRef]

8. Robinson, K.; Atherton, J.C. The Spectrum of Helicobacter-Mediated Diseases. Annu. Rev. Pathol. 2021, 16, 123-144. [CrossRef]

9. Tsay, F.W.; Hsu, P.I. H. pylori infection and extra-gastroduodenal diseases. J. Biomed. Sci. 2018, 25, 65. [CrossRef]

10. Blanchard, T.G.; Nedrud, J.G. Laboratory maintenance of helicobacter species. Curr. Protoc. Microbiol. 2006. [CrossRef]

11. Testerman, T.L.; McGee, D.J.; Mobley, H.L. Helicobacter pylori growth and urease detection in the chemically defined medium Ham's F-12 nutrient mixture. J. Clin. Microbiol. 2001, 39, 3842-3850. [CrossRef] [PubMed]

12. Bayona-Rojas, M. Microbiological conditions for culturing Helicobacter Pylori. Rev. Colomb. Gastroenterol. 2013, $28,94-99$.

13. Chen, C.; Pande, K.; French, S.D.; Tuch, B.B.; Noble, S.M. An iron homeostasis regulatory circuit with reciprocal roles in Candida albicans commensalism and pathogenesis. Cell Host Microbe 2011, 10, 118-135. [CrossRef]

14. Merrell, D.S.; Thompson, L.J.; Kim, C.C.; Mitchell, H.; Tompkins, L.S.; Lee, A.; Falkow, S. Growth phase-dependent response of Helicobacter pylori to iron starvation. Infect. Immun. 2003, 71, 6510-6525. [CrossRef] [PubMed]

15. Cover, T.L. Perspectives on methodology for in vitro culture of Helicobacter pylori. Methods Mol. Biol. 2012, 921, 11-15. [CrossRef]

16. Pich, O.Q.; Merrell, D.S. The ferric uptake regulator of Helicobacter pylori: A critical player in the battle for iron and colonization of the stomach. Future Microbiol. 2013, 8, 725-738. [CrossRef]

17. El Batawi, H.Y.; Venkatachalam, T.; Francis, A.; Abujabal, R.; Shehadat, S.A. Dental Caries-A Hiding Niche for Helicobacter pylori in Children. J. Clin. Pediatr. Dent. 2020, 44, 90-94. [CrossRef]

18. Kadota, T.; Hamada, M.; Nomura, R.; Ogaya, Y.; Okawa, R.; Uzawa, N.; Nakano, K. Distribution of Helicobacter pylori and Periodontopathic Bacterial Species in the Oral Cavity. Biomedicines 2020, 8, 161. [CrossRef]

19. Iwai, K.; Watanabe, I.; Yamamoto, T.; Kuriyama, N.; Matsui, D.; Nomura, R.; Ogaya, Y.; Oseko, F.; Adachi, K.; Takizawa, S.; et al. Association between Helicobacter pylori infection and dental pulp reservoirs in Japanese adults. BMC Oral Health 2019, 19, 267. [CrossRef]

20. Junqueira, A.C.M.; Ratan, A.; Acerbi, E.; Drautz-Moses, D.I.; Premkrishnan, B.N.V.; Costea, P.I.; Linz, B.; Purbojati, R.W.; Paulo, D.F.; Gaultier, N.E.; et al. The microbiomes of blowflies and houseflies as bacterial transmission reservoirs. Sci. Rep. 2017, 7, 16324. [CrossRef]

21. Castillo, M.; Bernabe, L.; Castaneda, C.A.; Chavez, I.; Ruiz, E.; Barreda, F.; Valdivia, D.; Suarez, N.; Nieves, J.; Dias-Neto, E.; et al. Helicobacter Pylori Detected in Tap Water of Peruvian Patients with Gastric Cancer. Asian Pac. J. Cancer Prev. 2019, 20, $3193-3196$. [CrossRef] [PubMed]

22. Mashak, Z.; Jafariaskari, S.; Alavi, I.; Sakhaei Shahreza, M.; Safarpoor Dehkordi, F. Phenotypic and Genotypic Assessment of Antibiotic Resistance and Genotyping of vacA, cagA, iceA, oipA, cagE, and babA2 Alleles of Helicobacter pylori Bacteria Isolated from Raw Meat. Infect. Drug Resist. 2020, 13, 257-272. [CrossRef] [PubMed]

23. Elhariri, M.; Hamza, D.; Elhelw, R.; Hamza, E. Occurrence of cagA + vacA s1a m1 i1 Helicobacter pylori in farm animals in Egypt and ability to survive in experimentally contaminated UHT milk. Sci. Rep. 2018, 8, 14260. [CrossRef] [PubMed]

24. Can, F.; Karahan, C.; Dolapci, I.; Demirbilek, M.; Tekeli, A.; Arslan, H. Urease activity and urea gene sequencing of coccoid forms of H. pylori induced by different factors. Curr. Microbiol. 2008, 56, 150-155. [CrossRef]

25. Nilsson, H.O.; Blom, J.; Abu-Al-Soud, W.; Ljungh, A.A.; Andersen, L.P.; Wadström, T. Effect of cold starvation, acid stress, and nutrients on metabolic activity of Helicobacter pylori. Appl. Environ. Microbiol. 2002, 68, 11-19. [CrossRef] [PubMed]

26. Shao, C.; Sun, Y.; Wang, N.; Yu, H.; Zhou, Y.; Chen, C.; Jia, J. Changes of proteome components of Helicobacter pylori biofilms induced by serum starvation. Mol. Med. Rep. 2013, 8, 1761-1766. [CrossRef]

27. Santus, W.; Devlin, J.R.; Behnsen, J. Crossing Kingdoms: How the Mycobiota and Fungal-Bacterial Interactions Impact Host Health and Disease. Infect. Immun. 2021, 89, e00620-e0648. [CrossRef]

28. Al-Rusan, R.M.; Darwazeh, A.M.G.; Lataifeh, I.M. The relationship of Candida colonization of the oral and vaginal mucosae of mothers and oral mucosae of their newborns at birth. Oral Surg. Oral Med. Oral Pathol. Oral Radiol. 2017, 123, 459-463. [CrossRef]

29. Linda, A.W.-F.; Walker, M.W.; Richard, J.H.; Pfaller, M.A.; James, E.; Ferguson, J.E., II; Wenzel, R.P.; Leigh, G.D. Vertical and Horizontal Transmission of Unique Candida Species to Premature Newborns. Clin. Infect. Dis. 1996, $22,803-808$. 
30. Salmanian, A.-H.; Siavoshi, F.; Beyrami, Z.; Latifi-Navid, S.; Tavakolian, A.; Sadjadi, A. Foodborne Yeasts Serve as Reservoirs of Helicobacter Pylori. J. Food Saf. 2012, 32, 152-160. [CrossRef]

31. Salmanian, A.H.; Siavoshi, F.; Akbari, F.; Afshari, A.; Malekzadeh, R. Yeast of the oral cavity is the reservoir of Heliobacter pylori. J. Oral Pathol. Med. 2008, 37, 324-328. [CrossRef]

32. Siavoshi, F.; Salmanian, A.H.; Akbari, F.; Malekzadeh, R.; Massarrat, S. Detection of Helicobacter pylori-specific genes in the oral yeast. Helicobacter 2005, 10, 318-322. [CrossRef]

33. Matamala-Valdés, L.; Sánchez-Alonzo, K.; Parra, C.; Sáez, K.; Aguayo-Reyes, A.; García, A. Detection of intracellular Helicobacter pylori in Candida. SPP from neonate oral swabs. Rev. Assoc. Med. Bras. (1992) 2018, 64, 928-935. [CrossRef]

34. Sánchez-Alonzo, K.; Matamala-Valdés, L.; Parra-Sepúlveda, C.; Bernasconi, H.; Campos, V.L.; Smith, C.T.; Sáez, K.; GarcíaCancino, A. Intracellular Presence of Helicobacter pylori and Its Virulence-Associated Genotypes within the Vaginal Yeast of Term Pregnant Women. Microorganisms 2021, 9, 131. [CrossRef] [PubMed]

35. Sánchez-Alonzo, K.; Parra-Sepúlveda, C.; Vergara, L.; Bernasconi, H.; García-Cancino, A. Detection of Helicobacter pylori in oral yeasts from students of a Chilean university. Rev. Assoc. Med. Bras. (1992) 2020, 66, 1509-1514. [CrossRef]

36. Siavoshi, F.; Taghikhani, A.; Malekzadeh, R.; Sarrafnejad, A.; Kashanian, M.; Jamal, A.S.; Saniee, P.; Sadeghi, S.; Sharifi, A.H. The role of mother's oral and vaginal yeasts in transmission of Helicobacter pylori to neonates. Arch. Iran. Med. 2013, 16, $288-294$.

37. Siavoshi, F.; Saniee, P. Vacuoles of Candida yeast as a specialized niche for Helicobacter pylori. World J. Gastroenterol. 2014, 20, 5263-5273. [CrossRef]

38. Sánchez-Alonzo, K.; Parra-Sepúlveda, C.; Vega, S.; Bernasconi, H.; Campos, V.L.; Smith, C.T.; Sáez, K.; García-Cancino, A. In Vitro Incorporation of Helicobacter pylori into Candida albicans Caused by Acidic pH Stress. Pathogens 2020, 9, 489. [CrossRef] [PubMed]

39. Böckelmann, U.; Manz, W.; Neu, T.R.; Szewzyk, U. Investigation of lotic microbial aggregates by a combined technique of fluorescent in situ hybridization and lectin-binding-analysis. J. Microbiol. Methods 2002, 49, 75-87. [CrossRef]

40. Rüssmann, H.; Kempf, V.A.; Koletzko, S.; Heesemann, J.; Autenrieth, I.B. Comparison of fluorescent in situ hybridization and conventional culturing for detection of Helicobacter pylori in gastric biopsy specimens. J. Clin. Microbiol. 2001, 39, 304-308. [CrossRef] [PubMed]

41. Senkovich, O.; Ceaser, S.; McGee, D.J.; Testerman, T.L. Unique host iron utilization mechanisms of Helicobacter pylori revealed with iron-deficient chemically defined media. Infect. Immun. 2010, 78, 1841-1849. [CrossRef] [PubMed]

42. Gulec, S.; Anderson, G.J.; Collins, J.F. Mechanistic and regulatory aspects of intestinal iron absorption. Am. J. Physiol. Gastrointest. Liver Physiol. 2014, 307, G397-G409. [CrossRef]

43. Huang, Y.; Wang, Q.-1.; Cheng, D.-d.; Xu, W.-t.; Lu, N.-h. Adhesion and Invasion of Gastric Mucosa Epithelial Cells by Helicobacter pylori. Front. Cell. Infect. Microbiol. 2016, 6, 159. [CrossRef]

44. Posselt, G.; Crabtree, J.E.; Wessler, S. Proteolysis in Helicobacter pylori-Induced Gastric Cancer. Toxins 2017, 9, 134. [CrossRef]

45. Zhou, Y.N.; Coleman, W.G.; Yang, Z.; Yang, Y.; Hodgson, N.; Chen, F.; Jin, D.J. Regulation of cell growth during serum starvation and bacterial survival in macrophages by the bifunctional enzyme SpoT in Helicobacter pylori. J. Bacteriol. 2008, 190, 8025-8032. [CrossRef] [PubMed]

46. Wells, D.H.; Gaynor, E.C. Helicobacter pylori Initiates the Stringent Response upon Nutrient and pH Downshift. J. Bacteriol. 2006, 188, 3726-3729. [CrossRef] [PubMed]

47. Ning, Y.; Hu, X.; Ling, J.; Du, Y.; Liu, J.; Liu, H.; Peng, Z. Candida albicans survival and biofilm formation under starvation conditions. Int. Endod. J. 2013, 46, 62-70. [CrossRef]

48. Rodrigues, C.F.; Rodrigues, M.E.; Silva, S.; Henriques, M. Candida glabrata Biofilms: How Far Have We Come? J. Fungi 2017, 3, 11. [CrossRef]

49. Delgado, M.L.; Gil, M.L.; Gozalbo, D. Starvation and temperature upshift cause an increase in the enzymatically active cell wall-associated glyceraldehyde-3-phosphate dehydrogenase protein in yeast. FEMS Yeast Res. 2003, 4, 297-303. [CrossRef]

50. Kumar, K.; Askari, F.; Sahu, M.S.; Kaur, R. Candida glabrata: A Lot More Than Meets the Eye. Microorganisms 2019, 7, 39. [CrossRef]

51. Ansorg, R.; Schmid, E.N. Adhesion of Helicobacter pylori to yeast cells. Zent. Bakteriol. 1998, 288, 501-508. [CrossRef]

52. Van Dyck, K.; Viela, F.; Mathelié-Guinlet, M.; Demuyser, L.; Hauben, E.; Jabra-Rizk, M.A.; Vande Velde, G.; Dufrêne, Y.F.; Krom, B.P.; Van Dijck, P. Adhesion of Staphylococcus aureus to Candida albicans During Co-Infection Promotes Bacterial Dissemination Through the Host Immune Response. Front. Cell. Infect. Microbiol. 2020, 10, 624839. [CrossRef]

53. Shing, S.R.; Ramos, A.R.; Patras, K.A.; Riestra, A.M.; McCabe, S.; Nizet, V.; Coady, A. The Fungal Pathogen Candida albicans Promotes Bladder Colonization of Group B Streptococcus. Front. Cell. Infect. Microbiol. 2020, 9, 437. [CrossRef] [PubMed]

54. Beaussart, A.; Herman, P.; El-Kirat-Chatel, S.; Lipke, P.N.; Kucharíková, S.; Van Dijck, P.; Dufrêne, Y.F. Single-cell force spectroscopy of the medically important Staphylococcus epidermidis-Candida albicans interaction. Nanoscale 2013, 5, 10894-10900. [CrossRef] [PubMed]

55. Hoyer, L.L.; Oh, S.-H.; Jones, R.; Cota, E. A proposed mechanism for the interaction between the Candida albicans Als3 adhesin and streptococcal cell wall proteins. Front. Microbiol. 2014, 5, 564. [CrossRef]

56. Dubois, A. Intracellular Helicobacter pylori and gastric carcinogenesis: An "old" frontier worth revisiting. Gastroenterology 2007, 132, 1177-1180. [CrossRef] 
57. Karczewska, E.; Wojtas, I.; Sito, E.; Trojanowska, D.; Budak, A.; Zwolinska-Wcislo, M.; Wilk, A. Assessment of co-existence of Helicobacter pylori and Candida fungi in diseases of the upper gastrointestinal tract. J. Physiol. Pharmacol. 2009, 60 (Suppl. S6), 33-39.

58. Reshetnyak, V.I.; Reshetnyak, T.M. Significance of dormant forms of Helicobacter pylori in ulcerogenesis. World J. Gastroenterol. 2017, 23, 4867-4878. [CrossRef]

59. Smits, G.J.; Kapteyn, J.C.; van den Ende, H.; Klis, F.M. Cell wall dynamics in yeast. Curr. Opin. Microbiol. 1999, $2,348-352$. [CrossRef]

60. Ingle, S.; Kazi, R.; Patil, R.; Zore, G. Proteome analysis of Candida albicans cells undergoing chlamydosporulation. J. Proteins Proteom. 2019, 10, 269-290. [CrossRef]

61. Saniee, P.; Siavoshi, F.; Nikbakht Broujeni, G.; Khormali, M.; Sarrafnejad, A.; Malekzadeh, R. Localization of H.pylori within the vacuole of Candida yeast by direct immunofluorescence technique. Arch. Iran. Med. 2013, 16, 705-710. [PubMed] 